\title{
Online Teacher Training of Cognition and Learning in Education
}

\author{
Danielle E. Kaplan \\ California School of Education, Alliant International University, San Francisco, USA \\ Email:dkaplan@alliant.edu
}

How to cite this paper: Kaplan, D. E. (2017). Online Teacher Training of Cognition and Learning in Education. Psycholo gy, 8, 373-386.

https://doi.org/10.4236/psych.2017.83023

Received: December 14, 2016 Accepted: February 12, 2017

Published: February 16, 2017

Copyright $\odot 2017$ by author and Scientific Research Publishing Inc. This work is licensed under the Creative Commons Attribution International License (CC BY 4.0).

http://creativecommons.org/licenses/by/4.0/

\begin{abstract}
Cognition is at the core of educational and all activity among sentient life. Yet, not enough settings, including educational settings, consciously apply cognitive principles. The value of including cognition in the education of all beings is clear, developing thinking and knowledge. It is of particular importance to incorporate cognitive theory into the training of teachers to further application of cognition in the instruction of all students. This research describes the creation of an online course dedicated toward facilitating the development of understanding of cognition and critical thinking in education and furthering its application by teachers in instruction, learning, and assessment.
\end{abstract}

\section{Keywords}

Cognition, Psychology, Education, Learning, Teacher Training, Critical Thinking, Behaviorism, Constructivism

\section{Introduction}

The California School of Education at Alliant International University has included a course in Critical Thinking for Teaching and Learning in a sequence of courses designed to prepare current and future educators to develop today and tomorrow's thinkers. There were many considerations for how to design the master course of study and mode of study, including accessibility, need, and value. Included in the course are overarching frameworks guiding design, core relevant content, poignant and significant assignments, and meaningful communication. Course learning outcomes include critiquing cognition and critical thinking theories in teaching and learning and applying cognition and critical thinking theories in education. Learning Outcomes meet School Conceptual Frameworks and California Department of Education Standards. Regular attendance is expected in consistent participation and submission of coursework. A 
code of ethics includes honesty and responsibility. Accommodations are provided for individuals with disabilities and religious/cultural/spiritual observance.

The overarching objective of this research is to develop the cognitive abilities of all beings by developing the study of cognition and learning in the training of teachers. A further objective is to develop the online instructional technologies to accomplish this goal. This paper describes The University, School, and State Guiding Frameworks and the design of the course, including the resources and activities in each module.

\section{University, School, and State Frameworks Guiding Design}

\subsection{University Mission Statement}

Alliant International University prepares students for professional careers of service and leadership and promotes the discovery and application of knowledge to improve the lives of people in diverse cultures and communities around the world. Alliant is committed to excellence in four areas:

Education for Professional Practice: Alliant's educational programs are designed to give students the knowledge, skills and ethical values they need to serve and lead effectively in a variety of professional settings. Alliant graduates are expected to achieve mastery of a body of knowledge and be able to apply that knowledge in professional practice in order to achieve desired and beneficial outcomes.

Scholarship: Scholarship in the Alliant context includes the discovery of new knowledge; the discovery of new applications of knowledge to solve practical problems; the integration of knowledge in new ways; and innovation in teaching knowledge and professional competencies.

Multicultural and International Competence: Alliant is an inclusive institution committed to serving diverse populations around the world by preparing professionals to work effectively across cultural and national boundaries, by increasing the number of professionals working in underserved areas, and by understanding and responding to the needs of diverse communities.

Community Engagement: Alliant's faculty, students, alumni and staff are dedicated to making a positive difference in the world through professional education and practice. We measure the success of our university in part by the impact we have, both directly and indirectly, on the welfare of individuals, families, organizations and communities.

\subsection{The California School of Education}

Alliant International University offers a full spectrum of credential, certificate and degree programs designed to address the educational needs of all learners in the 21st century, from infancy and entry into P-12 education system through adult life. Each program integrates significant, evidence-based, data-driven educational concepts into coursework, focusing on what is successful in education for diverse populations. The California School of Education's mission and vision 
statements reaffirm our values and commitment to collaboration, diversity, and service to candidates, shared leadership, and the continuous support of the education profession.

Mission: CSOE prepares competent, confident, and conscientious educational leaders who will promote and empower personal growth, academic success, and professional achievement for all in a global society.

Vision: To develop and promote transformative educational experiences that optimize human potential.

Goals: The California School of Education has a set of overarching goals that drive the direction of the School's programs and internal and external operations:

1) To provide the education and training of well-rounded professionals who will serve local, national and global schools and organizations.

2) To engage and partner with communities to translate professional practice and research to meet education needs.

3) To promote an academic culture of support to develop and apply transformative approaches to solve complex societal challenges.

4) To develop analytic skills and sound judgment as applied to content and professional issues.

5) To make warranted and thoughtful decisions about curriculum issues, student-related concerns and leadership that relate to the conduct of the school and the profession.

6) To provide professional educational opportunities for those who aspire to leadership in education settings.

7) To prepare candidates to meet the needs of all learners.

\subsection{Unit Guiding Principles}

CSOE's guiding principles are anchored in the belief that our mission is realized when our candidates are equipped with the skills to operationalize LEAD. LEAD stands for Leadership (L) Engagement (E) Application (A) and Dedication (D). As leaders, candidates demonstrate social responsibility, ethical action, and a commitment to be agents of change to improve the lives of their communities (L). We highlight for our candidates the value of authentic and collaborative engagement in advancing our communities (E). We train our candidates to be reflective professionals who incorporate theory into best practices; and utilize the knowledge, skills, dispositions, habits of inquiry, and technology that their preparation has honed (A). Courses and assignments are intentionally designed to engage experiences that promote the understanding of theories, concepts, principles, methodologies and approaches that candidates can readily utilize for practice. As candidates in both initial and advanced stages engage in observations, field experiences, and clinical practice, they provide service to their learners/clients, while simultaneously making instructional decisions that are grounded in educational research and/or theory (D).

$$
\mathrm{L}=\text { Leadership: Innovation with Accountability }
$$


$\mathrm{E}=$ Engagement: Active Learning

A = Application: Theory to Practice

$\mathrm{D}=$ Dedication: Inclusive Excellence

\subsection{School Theoretical Framework}

CSOE is based on two main theoretical frameworks: Boyer's applied scholarship of learning and constructivist theory.

CSOE utilizes Boyer's model of the scholarship of application (Figure 1):

Boyer (1990) asserted the need for all disciplines to move beyond traditional research to engage the full scope of academic work. He posits that in order to advance disciplines holistically and to obtain rewards for professional practice, research should encompass four critical areas:

Discovery-Generating new and unique knowledge;

Teaching-Faculty and candidates creatively build bridges between their own understanding and their students' learning;

Application (later called Engagement)-Taking the new knowledge acquired and utilizing to solve society's problems; and

Integration-Using collaborative relationships to uncover new knowledge among disciplines (Boyer, 1990).

These four aspects of scholarship are of paramount importance to CSOE. Each of the four areas informs the guiding principles of LEAD for CSOE.

Scholarship of Discovery (L, E, A, D): We subscribe to the centrality of the need to advance inquiry that produces the disciplinary and professional knowledge that frames our candidate preparation and training (Boyer, 1990). We ensure that our candidates are prepared to foster an environment that supports inclusive excellence with the commitment and understanding necessary to be responsive to all learners (D). Candidates acquire the ability to collaborate successfully (E) with parents, families, school districts, community members, faculty and staff in order to gain and maintain this disposition.

Scholarship of Teaching (L, E, A, D): CSOE subscribes to Boyer's model that

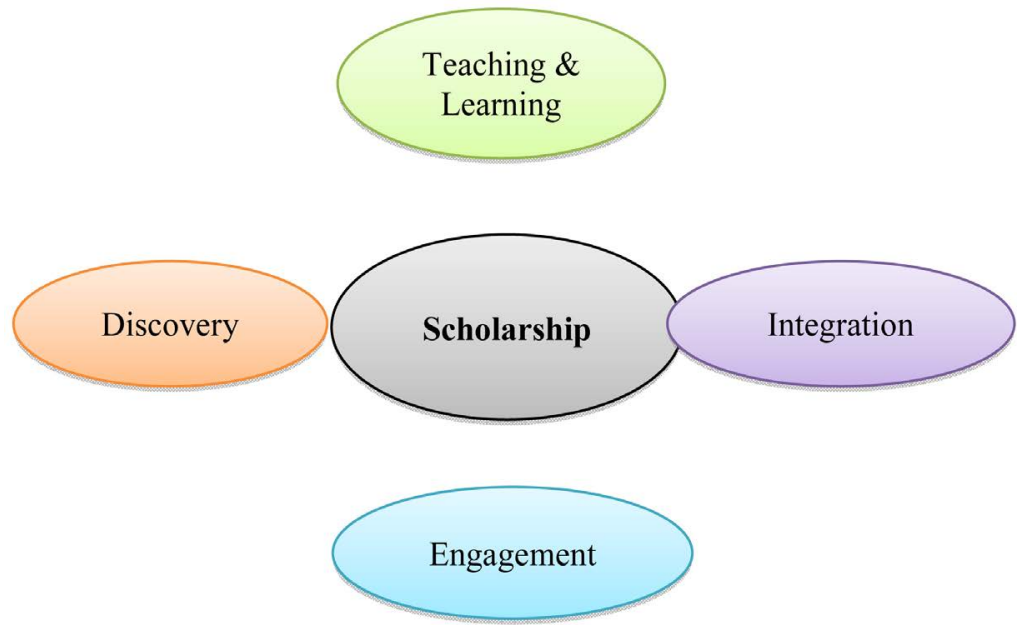

Figure 1. Boyer's model. 
underscores the notion of the scholarship of teaching as inquiry that produces knowledge to facilitate the transfer of the science and art of teaching, counseling and leadership from expert to novice. Thus we are very intentional in stewarding our mentoring relationships between faculty, school district master teachers, school site supervisors and our advisory boards. We view these relationships as critical to the transfer of teaching knowledge.

Scholarship of Professional Practice (A): Professional practice in CSOE is comprised of all aspects of the delivery of education, counseling, and leadership. Competence in practice is determined in school setting practicums and internships. Professional Practice is also the mechanism through which CSOE provides the environment and skills by which knowledge in the profession is both advanced and applied. In this segment, we also include the mentoring of candidates and leadership roles in developing practice. In all of the above, we highlight the scholarship generated through practice. Our Faculty and candidate professional certifications, degrees, and credentials and other specialty credentials demonstrate CSOE's attainments in this sphere.

Scholarship of Integration (L, E, A): In this sphere, faculty and candidates engage in the review and analysis of education policy, integrative models across disciplines, literature review and use all these to develop transdisciplinary educational programs and projects. Further, CSOE faculty are active and present at national and international conferences, serve on the leadership of professional organizations and contribute to journal articles. These are examples of how CSOE demonstrates the scholarship of integration. The guiding principles and candidate competencies are framed with the understanding that effective learning environments are social and collaborative in nature (Vygotsky, 1978).

The second theoretical underpinning for CSOE is constructivism. We concur with the assertion that our candidates and their students are active makers of meaning, rather than passive absorbers of knowledge (Dewey, 1944; Vygotsky, 1962; Brosio, 2000).

We expect our candidates to engage social constructivism by utilizing existing knowledge, interests, attitudes, and goals to select and interpret available information. Our faculty recognize the insider knowledge our candidates' bring to our courses and provide the environment for them to utilize their uniquely personal knowledge to create meaning as they integrate these knowledge bases with their diverse cultural, ethnic, social, and economic circumstances through analysis, reflection, and research.

We model a humanistic learning environment that encourages critical inquiry to connect learners with one another. Faculty members create caring environments where candidates are encouraged and supported to reach beyond themselves and to engage various points of view, diversity of ideas and practices.

\subsection{Course Learning Outcome Frameworks and Standards}

Course Learning Outcomes meet School Conceptual Frameworks Principles of Leadership, Engagement and Application, CSTP Standards 1 and 2, and TPEs, 
$1.5,3.3,3.6,3.8$, and 6.5 .

\subsubsection{California Standards for the Teaching Profession (CSTP) (from the California Commission on Teacher Credentialing Website) \\ Standard 1: Program Design and Curriculum}

Standard 2: Preparing Candidates to Master the Teaching Performance Expectations (TPEs)

\subsubsection{Teaching Performance Expectations (TPEs) (from the California Commission on Teacher Credentialing Website) \\ TPE 1: Engaging and Supporting All Students in Learning}

1.5: Promote students' critical and creative thinking and analysis through activities that provide opportunities for inquiry, problem solving, responding to and framing meaningful questions, and reflection.

TPE 3: Understanding and Organizing Subject Matter for Student Learning

3.3: Plan, design, implement, and monitor instruction consistent with current subject-specific pedagogy in the content area(s) of instruction, and design and implement disciplinary and cross-disciplinary learning sequences, including integrating the visual and performing arts as applicable to the discipline.1

3.6: Use and adapt resources, standards-aligned instructional materials, and a range of technology, including assistive technology, to facilitate students' equitable access to the curriculum.

3.8: Demonstrate knowledge of effective teaching strategies aligned with the internationally recognized educational technology standards.

\section{TPE 6: Developing as a Professional Educator}

6.5: Demonstrate professional responsibility for all aspects of student learning and classroom management, including responsibility for the learning outcomes of all students, along with appropriate concerns and policies regarding the privacy, health, and safety of students and families. Beginning teachers conduct themselves with integrity and model ethical conduct for themselves and others.

\section{Cognition Content and Assignment Modules}

The course is divided into eight weekly modules covering cognition theories. Each module covers a set of theorists in cognition, learning and critical thinking. Modules include: Introduction to Psychology and Cognition, Behaviorist approaches, Constructivism and Piaget, Vygotsky and Bruner, Learning and Social Cognitive Theories, Cognitive and Metacognitive Development and Critical Thinking, Intelligence, Emotion and Creativity, and Assessment and Teaching of Critical Thinking. The modules are made up of resources including links to course content and assignments and communication forums. Resources include readings and applications. Assignments include reviewing and discussing application of theories, creation of artifacts applying theories, and evaluation of artifacts applying theories. Assignment categories include discussion, course project, 
and lesson plans. Additionally, the course includes a Syllabus, Announcements, Course Materials, Discussions, Conferences, Grades, Chat, and a Questions center.

\subsection{Module 1: Introduction to Psychology and Cognition}

Module 1 is an introduction to Psychology and Cognition. The goal of the module is to provide an overview of the field and overarching concepts. Learning objectives include analyzing the principles of psychology and cognitive theory and determining how to effectively apply principles of psychology and cognition. These objectives tie into the School guiding principles of Leadership, Engagement, and Application and California State Standards for the Teaching Profession (CSTP) and Teaching Performance Expectations (TPE) for CSTP Standard 1 Program Design and Curriculum, CSTP Standard 2 Preparing candidates to master the Teaching Performance Expectations, and TPEs 1.5, 3.3, 3.6, 3.8, 6.5.

The module is made up of readings, forums, and assignments. Readings include Stangor (2012), James (1890), Grider (1993), Huitt (2006), and Cacioppo \& Tassinary (1990). Each reading presents guiding and foundational theories of psychology and cognition. The assignments include designing a lesson plan to incorporate introductory theories in psychology and cognition and share a course project idea and find classmates with complementary ideas and goals to collaborate with on the course project.

\subsection{Behaviorism}

Module 2 is a unit on behaviorist theories of psychology in critical thinking and education. The goal of the module is to provide an overview of behaviorist theories. Learning objectives include analyzing principles of behaviorism and determining how to effectively apply the principles of behaviorism in lesson plan and project design. Learning objectives connect to School guiding Principles of Leadership, Application and Engagement, CSTP Standards 1 and 2, TPEs 1.5, 3.3, 3.6, 3.8, and 6.5.

The module is made up of readings, forums, and assignments. Readings include Cherry (2016), Skinner (1974), Standridge (2002), Culatta (2015), Danley, James, Mims, \& Simms (nd), Baum (2004), Peel (2005). Each reading presents foundational theories in behaviorism including Watson, Thorndike, Skinner, and Pavlov. Assignments include brainstorming in project groups over how to incorporate behaviorist theories into project design, researching technology for project, selecting insights from behaviorist theorists and incorporating into lesson designed in Module 1, and providing meaningful feedback to classmates' lesson designs.

\subsection{Piaget and Constructivism}

Module 3 is a unit on constructivism and Piagetian theories of psychology in critical thinking and education. The goal of the module is to provide an overview

of constructivist and Piagetian theories. Learning objectives include analyzing 
principles of Constructivism and Piagetian theories and determining how to effectively apply the principles of Constructivism and Piagetian theories in lesson plan and project design. Learning objectives connect to School guiding Principles of Leadership, Application and Engagement, CSTP Standards 1 and 2, TPEs 1.5, 3.3, 3.6, 3.8, and 6.5.

The module is made up of readings, forums, and assignments. Readings include

Fosnot \& Perry (1996), Huitt \& Hummel (2003), Piaget (1952), and Piaget \& Cook (1954). Each reading presents foundational theories in Constructivism and Piagetian theories. Assignments include brainstorming in project groups over how to incorporate Constructivism and Piagetian theories into project design, selecting insights from Constructivism and Piagetian theories and incorporating into lesson designed in Module 1 and 2, and providing meaningful feedback to classmates' lesson designs.

\subsection{Vygotsky and Bruner}

Module 4 is a unit on Vygotsky and Bruner's theories of psychology in critical thinking and education. The goal of the module is to provide an overview of Vygotsky and Bruner's theories. Learning objectives include analyzing principles of Vygotsky and Bruner's theories and determining how to effectively apply the principles of Vygotsky and Bruner's theories in lesson plan and project design. Learning objectives connect to School guiding Principles of Leadership, Application and Engagement, CSTP Standards 1 and 2, TPEs 1.5, 3.3, 3.6, 3.8, and 6.5.

The module is made up of readings, forums, and assignments. Readings include

Vygotsky (1930), Skinner (1974), Bruner (1976), and Bruner (2004). Each reading presents Vygotsky and Bruner's theories. Assignments include brainstorming in project groups over how to incorporate Vygotsky and Bruner's theories into project design, create main page of instructional Project website, selecting insights from Vygotsky and Bruner's theories and incorporating into lesson designed in Module 1, 2, and 3, and providing meaningful feedback to classmates' lesson designs.

\subsection{Learning Theory and Social Cognitive Learning Theory}

Module 5 is a unit on Learning and Social Learning theories of psychology in critical thinking and education. The goal of the module is to provide an overview of Learning and Social Learning theories. Learning objectives include analyzing principles of Learning and Social Learning theories and determining how to effectively apply the principles of Learning and Social Learning theories in lesson plan and project design. Learning objectives connect to School guiding Principles of Leadership, Application and Engagement, CSTP Standards 1 and 2, TPEs 1.5, 3.3, 3.6, 3.8, and 6.5.

The module is made up of readings, forums, and assignments. Readings include 
McLoed (2016), Bandura (1988), Dewey (1910), Bransford \& National Research Council (2000), and Zimmerman, Bonner, \& Kovach (1996). Each reading presents Learning and Social Learning theories. Assignments include brainstorming in project groups over how to incorporate Learning and Social Learning theories into project design, selecting insights from Learning and Social Learning theories and incorporating into lesson designed in Module 1, 2, 3, and 4 , and providing meaningful feedback to classmates' lesson designs.

\subsection{Cognitive and Metacognitive Development and Critical Thinking}

Module 6 is a unit on Cognitive and Metacognitive Development and Critical Thinking and education. The goal of the module is to provide an overview of Cognitive and Metacognitive Development and Critical Thinking theories. Learning objectives include analyzing principles of Cognitive and Metacognitive Development and Critical Thinking theories and determining how to effectively apply the principles of Cognitive and Metacognitive Development and Critical Thinking theories in lesson plan and project design. Learning objectives connect to School guiding Principles of Leadership, Application and Engagement, CSTP Standards 1 and 2, TPEs 1.5, 3.3, 3.6, 3.8, and 6.5.

The module is made up of readings, forums, and assignments. Readings include Willingham (2007), Rondamb (2014), Siegler (1989), Kuhn (2000, 1999), Snyder \& Snyder (2008), Kuhn, Black, Keselman, \& Kaplan (2000), Van Gelder (2005). Readings present Cognitive and Metacognitive Development and Critical Thinking theories. Assignments include brainstorming in project groups over how to incorporate Cognitive and Metacognitive Development and Critical Thinking theories into project design, selecting insights from Cognitive and Metacognitive Development and Critical Thinking theories and incorporating into lesson designed in Module 1, 2, 3, 4, and 5, and providing meaningful feedback to classmates' lesson designs.

\subsection{Intelligence, Emotion, and Creativity}

Module 7 is a unit on Intelligence, Emotion, and Creativity in critical thinking and education. The goal of the module is to provide an overview of Intelligence, Emotion, and Creativity theories. Learning objectives include analyzing principles of Intelligence, Emotion, and Creativity theories and determining how to effectively apply the principles of Intelligence, Emotion, and Creativity theories in lesson plan and project design. Learning objectives connect to School guiding Principles of Leadership, Application and Engagement, CSTP Standards 1 and 2, TPEs 1.5, 3.3, 3.6, 3.8, and 6.5.

The module is made up of readings, forums, and assignments. Readings include

Sternberg \& Grigorenko (2003), Goleman (2000), Becker (2003), Cherry (2016, Sternberg (2006), Sternberg (1996), and Gardner (1995). Readings present Intelligence, Emotion, and Creativity theories. Assignments include brains- 
torming in project groups over how to incorporate Intelligence, Emotion, and Creativity theories into project design, selecting insights from Intelligence, Emotion, and Creativity theories and incorporating into lesson designed in Module $1,2,3,4,5$, and 6 , and providing meaningful feedback to classmates' lesson designs.

\subsection{Bloom's Taxonomy and Assessing and Teaching Critical Thinking}

Module 8 is a unit on Bloom's Taxonomy and Assessing \& Teaching Cognition and Critical Thinking and education. The goal of the module is to provide an overview of Bloom's Taxonomy and Assessing \& Teaching Cognition and Critical Thinking theories. Learning objectives include analyzing principles of Bloom's Taxonomy and Assessing \& Teaching Cognition and Critical Thinking theories and determining how to effectively apply the principles of Bloom's Taxonomy and Assessing \& Teaching Cognition and Critical Thinking theories in lesson plan and project design. Learning objectives connect to School guiding Principles of Leadership, Application and Engagement, CSTP Standards 1 and 2, TPEs 1.5, 3.3, 3.6, 3.8, and 6.5.

The module is made up of readings, forums, and assignments. Readings include Armstrong (2016), Peirce (2006), Paul \& Nosich (1993), Van Gelder (2001), Enis (1993), Jonassen Carr, \& Yueh (1998). Readings present Bloom's Taxonomy and Assessing \& Teaching Cognition and Critical Thinking theories. Assignments include brainstorming in project groups over how to incorporate Bloom's Taxonomy and Assessing \& Teaching Cognition and Critical Thinking theories into project design and submitting project, selecting insights from Bloom's Taxonomy and Assessing \& Teaching Cognition and Critical Thinking theories and discussing, and evaluating classmates' projects.

\section{Meaningful Communication}

Central to development in online instruction is evocative interaction inspiring engaging discussion. Communication includes student to instructor engagement, student to student engagement, and instructor to student engagement. Student to instructor interaction includes submission of assignments and questions. Student to student interaction includes responses to each other's assignment submissions and discussions. Instructor to student engagement occurs in a one to one relationship and a one to many relationships with individual responses to work and group announcements and emails.

\section{Conclusion}

This design research is dedicated to improving thinking activity everywhere and elevating knowledge in general by improving the thinking abilities of humans through advancing expertise in teachers and students in cognition and learning. The process of building the course has led to innovations in what to include in online teacher training of cognition and how to encourage the activation of this 
knowledge in its application to education. Further research will include learning development in the course and instructional and learning progressions in the field from this development.

\section{References}

Armstrong, P. (2016). Bloom's Taxonomy. Nashville, TN: Vanderbilt University, The Center for Teaching. https://cft.vanderbilt.edu/guides-sub-pages/blooms-taxonomy/.

Bandura, A. (1988). Organisational Applications of Social Cognitive Theory. Australian Journal of Management, 13, 275. https://doi.org/10.1177/031289628801300210

Baum, W. M. (2004). Understanding Behaviorism: Behavior, Culture, and Evolution (2nd ed.). Indianapolis, IN: Wiley-Blackwell.

http://www.blackwellpublishing.com/content/bpl images/content store/sample chapt er/9781405112611/baum sample chapter understanding behaviourism.pdf

Becker, K. A. (2003). History of the Stanford-Binet Intelligence Scales: Content and Psychometrics. (Stanford-Binet Intelligence Scales, Fifth Edition Assessment Service Bulletin No. 1). Itasca, IL: Riverside Publishing.

Boyer, E. (1990). Scholarship Reconsidered: Priorities for the Professoriate. Princeton, NJ: The Carnegie Foundation for the Advancement of Teaching.

Bransford, J., \& National Research Council (U.S.) (2000). How People Learn: Brain, Mind, Experience, and School. Washington, D.C.: National Academies Press. http://0-search.ebscohost.com.library.alliant.edu/login.aspx?direct=true\&db=nlebk\&A

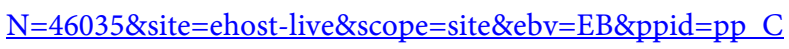

Brosio, G. (2000). Decentralisation in Africa. A Paper Prepared for African Department of the IMF.

Bruner, J. S. (1976). The Process of Education. Cambridge, US: Harvard University Press. http://0-site.ebrary.com.library.alliant.edu/lib/alliant/detail.action?docID $=10313833$.

Bruner, J. (2004). Life as Narrative. Social Research, 71, 691-710. http://0-search.proquest.com.library.alliant.edu/docview/209669779/1DF4F36875F648 95PQ/1?accountid=25255.

Cacioppo, J. T. \& Tassinary, L. G. (1990). Centenary of William James's Principles of Psychology: From the Chaos of Mental Life to the Science of Psychology. Personality and Social Psychology Bulletin, 16, 601-611. https://doi.org/10.1177/0146167290164002

Cherry, K. (2016). The Origins of Psychology: A Brief History of Psychology through the Years. https://www.verywell.com/the-origins-of-psychology-2795245

Cherry, K. (2016). What Are the Different Theories of Intelligence? https://www.verywell.com/theories-of-intelligence-2795035

Culatta, R. (2015). Behaviorist Learning Theory. http://www.innovativelearning.com/teaching/behaviorism.html

Danley, B., James, N., Mims, C., \& Simma, A. (nd). Behaviorism Theory: And Its Relation to Instructional Design. Macon, GA: Mercer University. http://faculty.mercer.edu/codone s/tco363/2014/behaviorism.pdf

Dewey, J. (1910). How We Think. Lexington, MA: D.C. Heath and Company. https://doi.org/10.1037/10903-000

Dewey, J. (1944). Democracy and Education. New York: The Free Press.

Enis, R. H. (1993). Critical Thinking Assessment. Theory into Practice, 32, 179-186. http://0-search.ebscohost.com.library.alliant.edu/login.aspx?direct=true\&db=ehh\&AN $\equiv 9311220797 \&$ site $=$ ehost-live\&scope $=$ site

https://doi.org/10.1080/00405849309543594 
Fosnot, C. T., \& Perry, R. S. (1996). Constructivism: A Psychological Theory of Learning. In C. T. Fosnot (Ed.), Constructivism: Theory, Perspectives, and Practice (pp. 8-33, 2nd ed.). New York: Teachers College Press. http://rsperry.com/wp-content/uploads/2015/10/Final-CHAPTER-2.pdf

Gardner, H. (1995). Reflections on Multiple Intelligences. Phi Delta Kappan, 77, 200. http://0-search.ebscohost.com.library.alliant.edu/login.aspx?direct=true\&db=ehh\&AN $\equiv 9512053705 \&$ site $=$ ehost-live $\&$ scope $=$ site

Goleman, D. (2000). Emotional Intelligence: Issues in Paradigm Building. In D. Goleman, \& C. Cherniss (Eds.), The Emotionally Intelligent Workplace: How to Select for, Measure, and Improve Emotional Intelligence in Individuals, Groups, and Organizations (pp. 1-13). San Francisco, CA: Jossey-Bass.

http://www.eiconsortium.org/reprints/ei issues in paradigm building.html

Grider, C. (1993). Foundations of Cognitive Theory: A Concise Review. Washington DC: ERIC. http://files.eric.ed.gov/fulltext/ED372324.pdf

Huitt, W. (2006). The Cognitive System. Educational Psychology Interactive, Valdosta, GA: Valdosta State University. http://www.edpsycinteractive.org/topics/cognition/cogsys.html

Huitt, W., \& Hummel, J. (2003). Piaget's Theory of Cognitive Development. Educational Psychology Interactive, Valdosta, GA: Valdosta State University. http://www.edpsycinteractive.org/topics/cognition/piaget.html

James, W. (1890). Principles of Psychology. New York, NY: Henry Holt and Company. https://doi.org/10.1037/11059-000

Jonassen, D. H., Carr, C., \& Yueh, H.-P. (1998). Computers as Mind Tools for Engaging Learners in Critical Thinking. TechTrends, 43, 24.

http://0-search.proquest.com.library.alliant.edu/docview/223133507?accountid=25255 https://doi.org/10.1007/BF02818172

Kuhn, D. (1999). A Developmental Model of Critical Thinking. Educational Researcher, 28, 16-46. http://0-edr.sagepub.com.library.alliant.edu/content/28/2/16.full.pdf + html https://doi.org/10.3102/0013189X028002016

Kuhn, D. (2000). Metacognitive Development. Current Directions in Psychological Science, 9, 178-181.

http://0-search.ebscohost.com.library.alliant.edu/login.aspx?direct=true\&db=aph\&AN $=4518944 \&$ site $=$ ehost-live $\&$ scope $=$ site https://doi.org/10.1111/1467-8721.00088

Kuhn, D., Black, J., Keselman, A., \& Kaplan, D. (2000). The Development of Cognitive Skills to Support Inquiry Learning. Cognition and Instruction, 18, 495-523. http://0-www.jstor.org.library.alliant.edu/stable/3233891 https://doi.org/10.1207/S1532690XCI1804 3

McLeod, S. A. (2016). Bandura-Social Learning Theory. http://www.simplypsychology.org/bandura.html

Paul, R., \& Nosich, G. M. (1993). A Model for the National Assessment of Higher Order Thinking. In R. Paul (Ed.), Critical Thinking: What Every Student Needs to Survive in a Rapidly Changing World (pp. 78-123). Dillon Beach, CA: Foundation for Critical Thinking.

https://www.criticalthinking.org/pages/a-model-for-the-national-assessment-of-higher -order-thinking/591

Peel, D. (2005). The Significance of Behavioural Learning Theory to the Development of Effective Coaching Practice. International Journal of Evidence Based Coaching and Mentoring, 3, 18-28. http://ijebcm.brookes.ac.uk/documents/vol03issue1-paper-02.pdf

Peirce, W. (2006). Designing Rubrics for Assessing Higher Order Thinking. Columbia, 
MD: Howard Community College.

http://academic.pgcc.edu/ wpeirce/MCCCTR/Designingrubricsassessingthinking.html

Piaget, J. (1952). The Origins of Intelligence in Children. New York, NY: W.W. Norton \& Co. https://doi.org/10.1037/11494-000

Piaget, J., \& Cook, M. (1954). The Construction of Reality in the Child. New York, NY: Basic Books. https://doi.org/10.1037/11168-000

Rondamb (2014). The Importance of Teaching Critical Thinking. Global Digital Citizen Foundation.

Skinner, B. F. (1974). About Behaviorism. New York: Vintage Books.

Siegler, R. S. (1989). Mechanisms of Cognitive Development. Annual Review of Psychology, 40, 353.

http://0-search.ebscohost.com.library.alliant.edu/login.aspx?direct=true\&db=aph\&AN $=11290246 \&$ site $=$ ehost-live\&scope $=$ site

https://doi.org/10.1146/annurev.ps.40.020189.002033

Snyder, L. G., \& Snyder, M. J. (2008). Teaching Critical Thinking and Problem Solving Skills. Delta Pi Epsilon Journal, 50, 90-99.

http://0-search.ebscohost.com.library.alliant.edu/login.aspx?direct=true\&db=bth\&AN $=36047753 \&$ site $=$ ehost-live $\&$ scope $=$ site

Standridge, M. (2002). Behaviorism. In M. Orey (Ed.), Emerging Perspectives on Learning, Teaching, and Technology.

http://epltt.coe.uga.edu/index.php?title=Behaviorism

Stangor, C. (2012). Introduction to Psychology. Washington DC: Saylor Academy. https://saylordotorg.github.io/text introduction-to-psychology/index.html

Sternberg, R. J. (2006). The Nature of Creativity. Creativity Research Journal, 18, 87-98. http://0-search.ebscohost.com.library.alliant.edu/login.aspx?direct=true\&db=ehh\&AN $=20032012 \&$ site $=$ ehost-live\&scope $=$ site https://doi.org/10.1207/s15326934crj1801 10

Sternberg, R. (1996). Myths, Countermyths, and Truths about Intelligence. Educational Researcher, 25, 11-16. http://0-www.jstor.org.library.alliant.edu/stable/1176335 https://doi.org/10.3102/0013189X025002011

Sternberg, R. J., \& Grigorenko, E. L. (2003). Teaching for Successful Intelligence: Principles, Procedures, and Practices. Journal for the Education of the Gifted, 27, 207-228.

Van Gelder, T. J. (2001) How to Improve Critical Thinking Using Educational Technology. In G. Kennedy, M. Keppell, C. McNaught, \& T. Petrovic (Eds.), Meeting at the Crossroads. Proceedings of the 18th Annual Conference of the Australasian Society for Computers in Learning in Tertiary Education (pp. 539-548). Melbourne: Biomedical Multimedia Unit, The University of Melbourne.

https://sites.google.com/site/timvangelder/publications-1/how-to-improve-critical-thin king-using-educational-technology

Van Gelder, T. (2005). Teaching Critical Thinking. College Teaching, 53, 41-46. http://0-search.ebscohost.com.library.alliant.edu/login.aspx?direct=true\&db=ehh\&AN $=15348172 \&$ site $=$ ehost-live\&scope $=$ site https://doi.org/10.3200/CTCH.53.1.41-48

Vygotsky, L. S. (1930). Mind and Society. Cambridge, MA: Harvard University Press. http://www.cles.mlc.edu.tw/ cerntcu/099-curriculum/Edu Psy/EP 03 New.pdf

Vygotsky, L. S. (1962). Thought and Language. Cambridge, MA: MIT Press. https://doi.org/10.1037/11193-000

Vygotsky, L. S. (1978). Mind in Society. Cambridge, MA: Harvard University Press.

Willingham, D. T. (2007). Critical Thinking: Why Is It So Hard to Teach? American 
Educator, 31, 8-19. http://www.aft.org/sites/default/files/periodicals/Crit Thinking.pdf

Zimmerman, B. J., Bonner, S., \& Kovach, R. (1996). Developing Self-Regulated Learners: beyond Achievement to Self-Efficacy. Washington DC: American Psychological Association.

http://0-web.a.ebscohost.com.library.alliant.edu/ehost $/$ command/detail? sid=64e5437c-

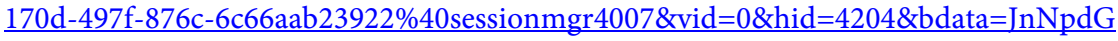
U9ZWhvc3QtbGl2ZSZzY29wZT1zaXRl\#db=pzh\&jid=199698621

https://doi.org/10.1037/10213-000

Submit or recommend next manuscript to SCIRP and we will provide best service for you:

Accepting pre-submission inquiries through Email, Facebook, LinkedIn, Twitter, etc. A wide selection of journals (inclusive of 9 subjects, more than 200 journals)

Providing 24-hour high-quality service

User-friendly online submission system

Fair and swift peer-review system

Efficient typesetting and proofreading procedure

Display of the result of downloads and visits, as well as the number of cited articles Maximum dissemination of your research work

Submit your manuscript at: http://papersubmission.scirp.org/

Or contact psych@scirp.org 